Mitteilungen der Österreichischen Geographischen Gesellschaft, 158. Jg. (Jahresband), Wien 2016, S. 215-244

\title{
Tracing the Military Frontier District of NăsăUd Territorial Identity and Regional Development
}

\author{
Oana-Ramona Ilovan, Ioana Scridon, Kinga Xénia Havadi-Nagy, \\ and Dănuţ HuCIU, all Cluj-Napoca*
}

with 3 figures in the text

\section{CONTENTS}

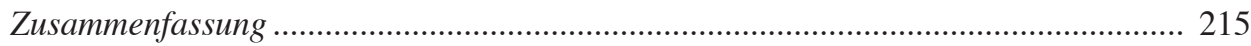

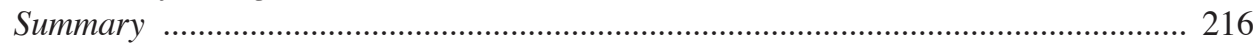

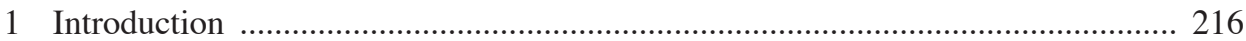

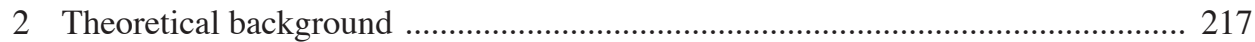

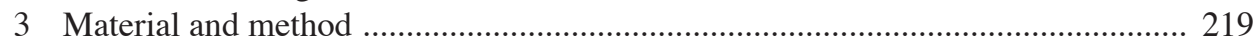

4 Results and discussion .................................................................................. 220

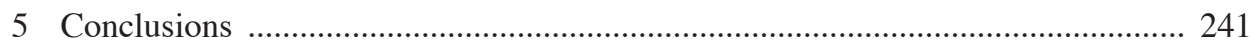

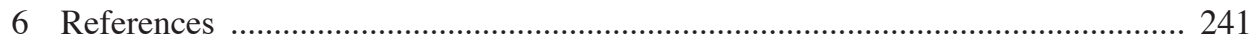

\section{Zusammenfassung}

Auf den Spuren des Militärgrenzbezirks Năsăud. Territoriale Identität und Regionalentwicklung

Raumbezogene Gruppenidentität ist ein wichtiger Faktor für den wirtschaftlichen, sozialen und territorialen Zusammenhalt. Aber ohne koordinierte lokale und regionale Initiativen verlieren selbst traditionsbewusste Gemeinschaften ihre Identitätsanker. Dieser Artikel verfolgt zwei Ziele: (1) die wichtigsten Identitätsmerkmale des Landes Năsăud im Norden Rumäniens zu erkunden und sie mit einer historischen Periode in Verbindung zu bringen, die für die soziale und wirtschaftliche Entwicklung der Region entscheidend war: die Zeit, als das Land Năsăud zur Österreichischen Militärgrenze gehörte (1762-1851); (2) anhand dieses Beispielsfalls empirisch zu belegen, welche Bedeutung raumbezogene Identität für die Regionalentwicklung hat. Das System der Militärgrenze, zur Mitte des 18.

\footnotetext{
* Oana-Ramona Ilovan, PhD., Lecturer; Ioana Scridon, PhD.; Kinga Xénia Havadi-Nagy, PhD., Lecturer; Dănuţ Hucıu, MSc., all Babeş-Bolyai University Cluj-Napoca, Faculty of Geography, Cluj-Napoca, Str. Clinicilor 5-7, RO-400006, Romania; email: ilovanoana@yahoo.com; scridon.ioana@yahoo.com; xenia. havadi@geografie.ubbcluj.ro; huciudanut@yahoo.com
} 
Jhs. eingeführt von Kaiserin Maria Theresia und dann weitergeführt von Kasier Joseph II., stieß auf örtliche Akzeptanz, weil damit Vorteile für die Bewohner verbunden waren und weil Wien die örtlichen politischen, kulturellen und sozio-ökonomischen Verhältnisse beachtete. Der Artikel beruht auf einer Umfrage zu identitätsstiftenden Merkmalen des Landes Năsăud. Zudem wurden aktuelle Initiativen analysiert, die auf regionsbezogener Identität gründen. Der Artikel schließt mit Vorschlägen von Entwicklungsmaßnahmen sowie mit dem Fazit, dass regionsbezogene Identität eine wichtige Ressource ist, dass sie die Entwicklungsinitiativen im Land Năsăud unterstützt, und dass dieses Prinzip auf Regionen ähnlicher Art übertragbar wäre - auf andere Teile der ehemaligen Militärgrenze, aber darüber hinaus auch auf andere Gebiete mit starkem Traditionsbewusstsein.

Schlagwörter: Năsăud, Österreichische Militärgrenze, raumbezogene Identität, Regionalentwicklung, Rumänien

\section{Summary}

Collective identity is a significant factor for economic, social and territorial cohesion, but in the absence of coordinated local and regional initiatives, traditional communities are running the risk of losing their values in the near future. The aim of our paper was (1) to explore the main identity features of the Land of Năsăud, Romania, tracing them back to a significant period for its social and economic development as a region: The Military Frontier District of Năsăud (1762-1851), part of the Austrian Military Frontier, and (2) to give empirical arguments that identity enables development. The success of implementing the institutionalised Military Frontier system in the mid-18th century (initiated by Maria Theresa and continued by Joseph II) was due to the civic spirit of the Habsburg Empire and to the characteristic situations of each territory, which was militarised. We employed a qualitative analysis of the data from a survey targeting the identity features of the region of Năsăud as perceived by its inhabitants and analysed the present activities based on territorial identity. We concluded with a series of development measures and that regional identity is a resource that supports development initiatives in the Land of Năsăud and implicitly in other 'land' type regions, in former Military Frontier districts, and in conservative regional communities.

Keywords: Năsăud, Austrian Military Frontier, space-related identity, regional development, Romania

\section{Introduction}

In Romania, different areas and periods exhibit different cohesion forms and in such a context, especially starting from the temporal perspective, it is important to research and learn about people's perception of their identity: Do they share the same values as the previous generation, do they have the same vision upon their life and upon the development 
of their community? How should one approach development starting from the identity features of the respective community?

The 'land' type regions are recognised in Romania for their territorial identity (ethnographical features, traditional occupations, and regional consciousness and pride) and therefore researchers consider them favourable for becoming once more, as in their history during certain periods, functional units for territorial planning and regional development. Time has proved that they are both static, due to maintaining certain characteristic features, and dynamic, as they have changed their territorial size according to their development. They regenerate themselves through internal effort and the human resource's features are a strength.

Restructuring meant diversifying activities and values, adapting to contemporary socio-political and economic circumstances while taking into account old customs, unwritten laws, and traditions. The 18 'lands' of Romania proved their feasibility while undergoing a remodelling process especially after 1990, during the social and economic transition that has had a significant material and spiritual impact on their regional communities.

The aim of our paper was both (1) to explore the main identity features of the Land of Năsăud (overlapping partly the homonymous former frontier district), Romania, tracing them back to a significant period for its social and economic development as a region: The Military Frontier District of Năsăud (1762-1851), part of the Austrian Military Frontier, and (2) to give empirical arguments that identity enables development and the strong identity of this region could be used in such a context.

The Land of Năsăud, situated in the northern half of Bistriţa-Năsăud County [Judeţul Bistriţa-Năsăud], has over 100,000 inhabitants and $80 \%$ of them live in the rural area (ILOVAN 2009). In order to understand its future development options, it is important to answer to the question "What do inhabitants identify themselves with nowadays?" We analysed how regional identity was turned to good account in relation to social capital, by identifying groups, associations, voluntary activities, organisations, projects, etc. and we proposed solutions for preserving regional identity and supporting future development.

\section{Theoretical background}

Recent research focuses on the role of identity as a resource for social capital, for territorial cohesion, for territorial planning, and for development in general. Collective identity is a significant factor for cohesion, but in the absence of coordinated local and regional initiatives, traditional communities are running the risk of losing their collective defining values in the near future (SCRIDON \& ILOVAN 2015).

A. PAASI regards identity as a "major watchword since the 1980s". In his work, he emphasises the importance of identity and synthesises its rather complicated discourse, especially at the regional level (stressing similarities, collective action, identity movements). The fact that the concept of identity had been reconsidered in fields such as geography, cultural/economic history, literature, anthropology, political science, sociology, psychology and musicology argues for its relevance (PAASI 2003, p. 475). PAASI also discussed 
the role of regions and identities (which he considered both historically and spatially contingent) for regional planning, as an institutional context for exploiting and employing regional identity (PAAsi 2011).

Similarly, in another study, PAASI (2009) considered regional identity "a major buzzword", especially for the European Union's (EU) cohesion policy and for regional development in general, due to the fact that it is "an idea at least implicitly indicating some cohesiveness or social integration in a region" and also because "regions are conceptualised here as processes that gain their boundaries, symbolisms and institutions in the process of institutionalisation" (for the institutionalisation processes, the power of the regional elites being of utmost importance) (PAASI 2009, p. 121). This institutionalisation of regions explaining the emergence of regions and the constitution of regional identity offered, in yet another of PAAsI's contributions (1986), also the theoretical framework for discussing the features of regional communities and of regional consciousness.

Moreover, Y.-F. TUAN (1990) first documented topophilia and, starting from this, new studies emerged, such as J. OliveIRA, Z. RocA and N. LeITAO's research on topophilia "and its enrichment in terms of development policy and actions seeking (re)affirmation of landscape-related and other territorial identity features" (Oliveira, RocA \& Leitao 2010, p. 801). In their work, they introduced the new concept of terraphilia, realised an assessment of the topophilia-terraphilia interface and an empirical delimitation and systematisation of the features of territorial identity (natural, economic, societal, and cultural). They also considered the sense of territorial belonging and territorial attractiveness as elements that had strategic relevance for local and regional development.

In addition, Z. RocA and M. DE NAZARÉ Oliveira-RocA (2007, p. 434) researched the (re)affirmation of territorial identity for places and regions arguing that this was an important development policy issue as proved by the research and policy agendas since the early 1990s. They discussed mainly the importance of territorial identity for local and regional development in certain rural areas of the peripheral and therefore lagging European regions. They mentioned the vulnerability of losing cultural authenticity and found a solution by creating a new conceptual-methodological framework for using territorial identity: "The gap between the pro-identity discourse and reality could be overcome if "territorial identity', basically an ambiguous and inoperative concept, would be transformed into an analytical category, susceptible to measurement, monitoring and evaluation." (RoCA \& DE NAZARÉ OliveIRA-Roca 2007, p. 434)

Similarly, J. LeE et al. (2005) examined the roles of social capital and identity in rural development, focusing on nowadays Western Europe. They researched the links between social capital and local identity and between those two and policy, as policy makers and academia considered them to trigger positive social and economic change. These researchers suggested that "a strong sense of identity can be understood as an aspect of social capital. We furthermore argue that social capital generally, and identities specifically, have to be understood as emanating from concrete social relationships." (LEE et al. 2005, p. 269) They used ethnographic methods (e.g. especially qualitative interviews) to understand the significance of identity in rural development and drew the conclusion that "development emerges from this dialectic of existing networking practices and networks that are instigated for the purposes of development." (LEE et al. 2005, p. 270) 
Also M. KeATing (2008, p. 99) takes into account three elements for analysing regional identity related to decision making factors (i.e. political action): The cognitive element (Inhabitants are aware of the region's existence, features, and geographical limits.), the affective element (the way they feel about the region and their relationship with it based on this), and the instrumental element (collective mobilisation and action within the region for achieving certain social, economic, and politic objectives).

In this context, the Europe of regions offers the necessary policies for promoting "the geographical personality" of places, as created in historical time (BLACHE 1903, apud Claval, p. 5) and for legitimising local communities as actors in their own development, an idea promoted by the paradigm of the New Regionalism (SсOTT 2009).

Finally, C. FlORA ButLER \& J. Flora (2013, p. 24) take into account for the structuring of the local and regional resource seven types of capital (natural, social, human, political, cultural, built, and financial). The cultural and social ones are the most relevant for our study. The cultural capital is made of historical elements, tradition and families that have an impact on the way we perceive the world around us and on our values. The regional features correlated to those three components for the Land of Năsăud are: Continuity of inhabiting the respective territory, geographical unity, mainly rural population, and the existence of a strong polarising centre, Năsăud, with educational significance (ILOVAN 2009, p. 418; Ilovan 2013a). The social capital in this region is based on mutual trust, on collective identity (ILOVAN 2008), on the practice of work together with the other members of the community based on projects and a sense of shared future (ILOvAn 2013b, p. 62).

\section{Material and method}

We employed a qualitative analysis of the data resulted from a survey during 2005 and 2007 targeting the main identity features of the region of Năsăud as perceived by its inhabitants. There were 54 respondents. 32 men and 22 women completed the questionnaire, representing more than half of those that we contacted in person with the request to do so. We did not try to ensure the representativeness of the sample as the aim was to analyse in a qualitative manner respondents' answers and a certain common view we identified while doing this analysis. We selected the respondents according to the criteria of representativeness to their community from a social and cultural perspective: Most of them were teachers and priests, people who knew the traditions and traditional way of life, values, and mentality. Most of these respondents have university education and this was an important criterion for selection due to the high difficulty of half the questions, which required an elaborated answer. A second criterion for selecting respondents was their origin. Therefore, we selected people who lived in the region, and also a few who came in frequent and close contact to the people of the region. We ensured respondents that they will be anonymous during our research and they agreed that we used their answers as research material realising a qualitative analysis of their discourse.

For the part on capitalising the territorial identity features resulted through the questionnaire, we mostly used official data (from online sites of the Local Action Groups, of 
associations, and diverse public institutions), and the local mass media (newspapers and cultural journals - the inhabitants' main information source). This part of data collection lasted for three months (February-May 2016).

\section{Results and discussion}

\subsection{Historical context}

The Austrian Military Frontier was a region that, in its culmination, stretched for 1,800 $\mathrm{km}$ along the eastern and south-eastern border of the Austrian Empire with the Ottoman Empire (Fig. 1). This establishment resulted through a process of power expansion and stabilisation, which occurred during the $16^{\text {th }}-18^{\text {th }}$ centuries. Fighting the demographical and social instability in the newly conquered peripheral areas, the persistent threat from the Ottoman Empire and given its own efforts of expansion in the Balkans, the Austrian Empire needed to re-inforce and protect its borders. Mobile troops were deployed in a territory placed under the jurisdiction of the Aulic War Council in Vienna [Wien]. To ensure the Austrian supremacy, the policy makers in Vienna developed a plan to re-inforce the sparsely populated border region by populating the new provinces. An exception was the last militarised area, the Transylvanian Military Frontier, where the administration relied on the existing local population. The system envisaged the combination of land ownership with military commitment and created a "farmer and soldier" population. The border guards' most important function was to ensure the security of the border and prevent the spread of epidemics. In times of war, they were mobilised not only on the south-eastern part of the Empire, but engaged on the battlefronts of the Austrian Empire across Europe (Havadi-Nagy 2013; Havadi-NaGy 2010).

Among the first forms of protecting the borders were the garrisons under the authority of the internal commissions of the government in Vienna. Certain sources recorded that the first forms of organising the Military Frontier were at the contact with the Ottoman Empire, the Croatian Frontier of the Empire respectively (1526) that had as a basis the medieval entrenchment system (ŠUgAR 2010, p. 54, apud AMSTADT 1969, p. 4). The institutionalised frontier system had a territorial development that lasted more than a century: The Slavonia [Slavonija] - Batschka [Bácska/Bačka] - Tisza - Mureş Frontier (1702), the Banat Frontier (1739-1742) and the Transylvania [Transilvania] Frontier (1764) (JoRdAn 2015, p. 247).

Implementing a frontier system within the Austrian Monarchy was a step towards further progress and to standardise and unify its autonomy. They planned this system through a large movement of researching the entire territory that was under the authority of the Austrian Monarchy. Several research committees were set up to study the situation of the territories to be militarised and analysed the issue of the frontiers from a social, strategic, and political perspective (VANIČEK 1875).

The Military Frontier underwent several stages of expansion, development, re-organisation and institutionalisation. From the mid- $18^{\text {th }}$ century, the Transylvanian Military Frontier was an extension of this defensive belt, which was finally suspended in 1851. 


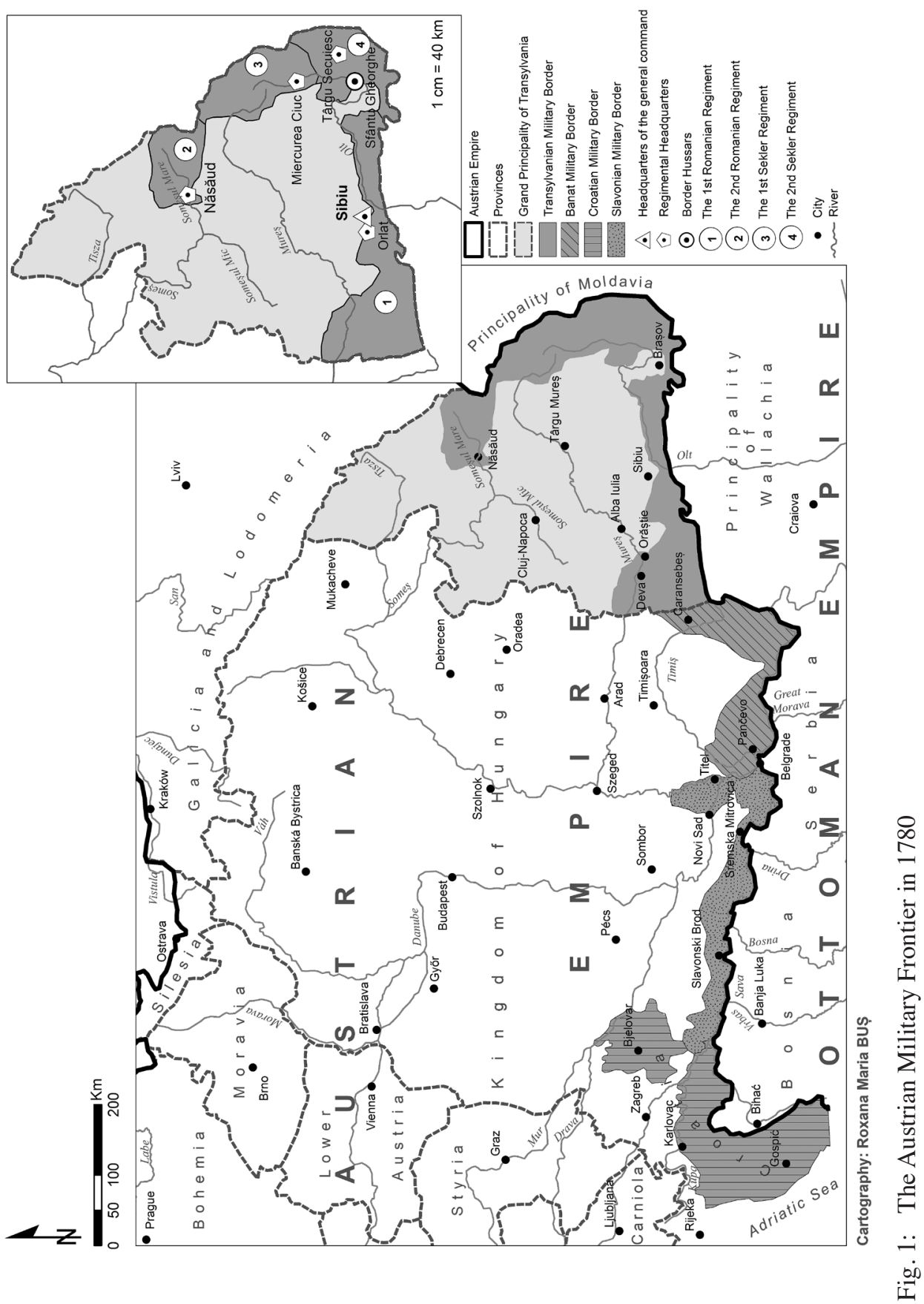


The Transylvanian section of the Military Frontier had the shortest existence, being created as last and dissolved as first. The internal commission from Vienna administered the Transylvanian Frontier (Siebenbürgische Grenze) between 1764 and 1851. The structure of the military administration within this frontier was the following: Two Wallachian regiments and three Hungarian ones, and the latter had also a role on the other part of the Carpathians through setting up three (out of the five) Szekler settlements in the south of Bucovina (JoRDAN 2015, p. 250). The $11^{\text {th }}$ Romanian Frontier Regiment was set up on the $1^{\text {st }}$ of April 1762 (including the present area of the Land of Năsăud) with the name of the Second Wallachian/Romanian Regiment.

The reasons for setting up the Transylvanian Frontier was that of creating a military unit that enforced the stableness of the area, that limited the noblemen's power, that lead to a decrease of emigration towards Moldavia [Moldova] and Walachia [Ţara Românească], that increased the workforce, and that prevented the spreading of epidemics caused by people's mobility (VLAȘIN 2012, pp. 11-12), but especially that ensured the better communication in the Empire by means of mail and that controlled commerce (JORDAN 2015, p. 245).

But the success of implementing the Military Frontier system in the mid-18 ${ }^{\text {th }}$ century in this part of the Empire was due not only to the Habsburg Empire's civic spirit, but also to the tensed situation in Northern Transylvania. On the surface, the main reasons for setting up the frontiers in the north-east of Transylvania, in the area of Năsăud, respectively, were those of protecting and strengthening the borders, of educating the people and of increasing their trust in the Monarchy by means of attributing them property, education, and religious rights. Beside these, there were also those of strengthening the economic, military, and religious positions of the Monarchy in the eastern part of their Empire. The regional and local reasons were both social and psychological. The initiative of the central administration came as an answer to the instability in the area caused by the revolts and the baffles between the inhabitants of the Someşul Mare Valley and the local administration ruler who was the magistrate of Bistriţa [Bistriţa/Bistritz] (VLAșin 2011, p. 86).

On the $13^{\text {th }}$ of October 1761, Baron Adolf Nicolaus Buccow (commander of the army in Transylvania) submits his project proposal for militarising the north-east of Transylvania, which he divided into seven regiments of infantry and cavalry (two Romanian and five Hungarian) (VLAșin 2012, pp. 11-12). The militarisation was not a forced one, but a long-standing process both in time and space (BUTA \& ONOFREIU 2012, p. 48), through endeavours of 'convincing the population' about the benefits of setting up a military system in the region. The frontier district, in the first phase of implementation, included 23 communes with about 4,300 families. Those settlements were in the following valleys: The Someşul, the Ilva, the Rebra, and the Ţibleş - in the present Land of Năsăud (an ethnographical region) (Fig. 2). In 1764, they started extending militarisation on the Şieu Valley and on the Mureş Valley, and in 1783 they included also the Bârgău Valley (Fig. 3). Comparing with the rest of the Military Frontier, where entire land stripes with their total population were militarised, in the Transylvanian district the militarisation was restricted upon village groups.

The main points that the general Buccow stressed were those of liberating the people from the leadership of the magistrate in Bistriţa and granting them the free people statute 


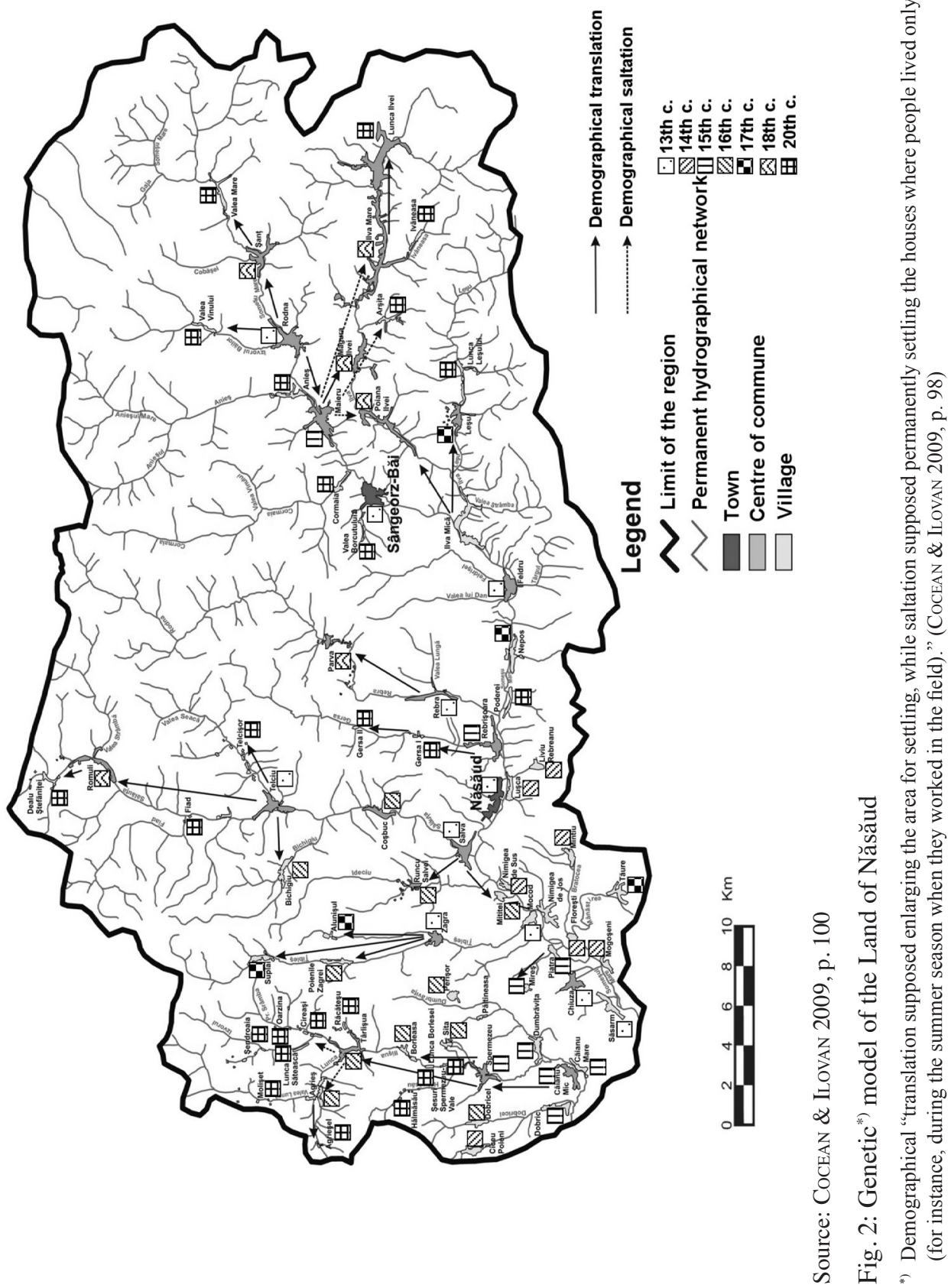



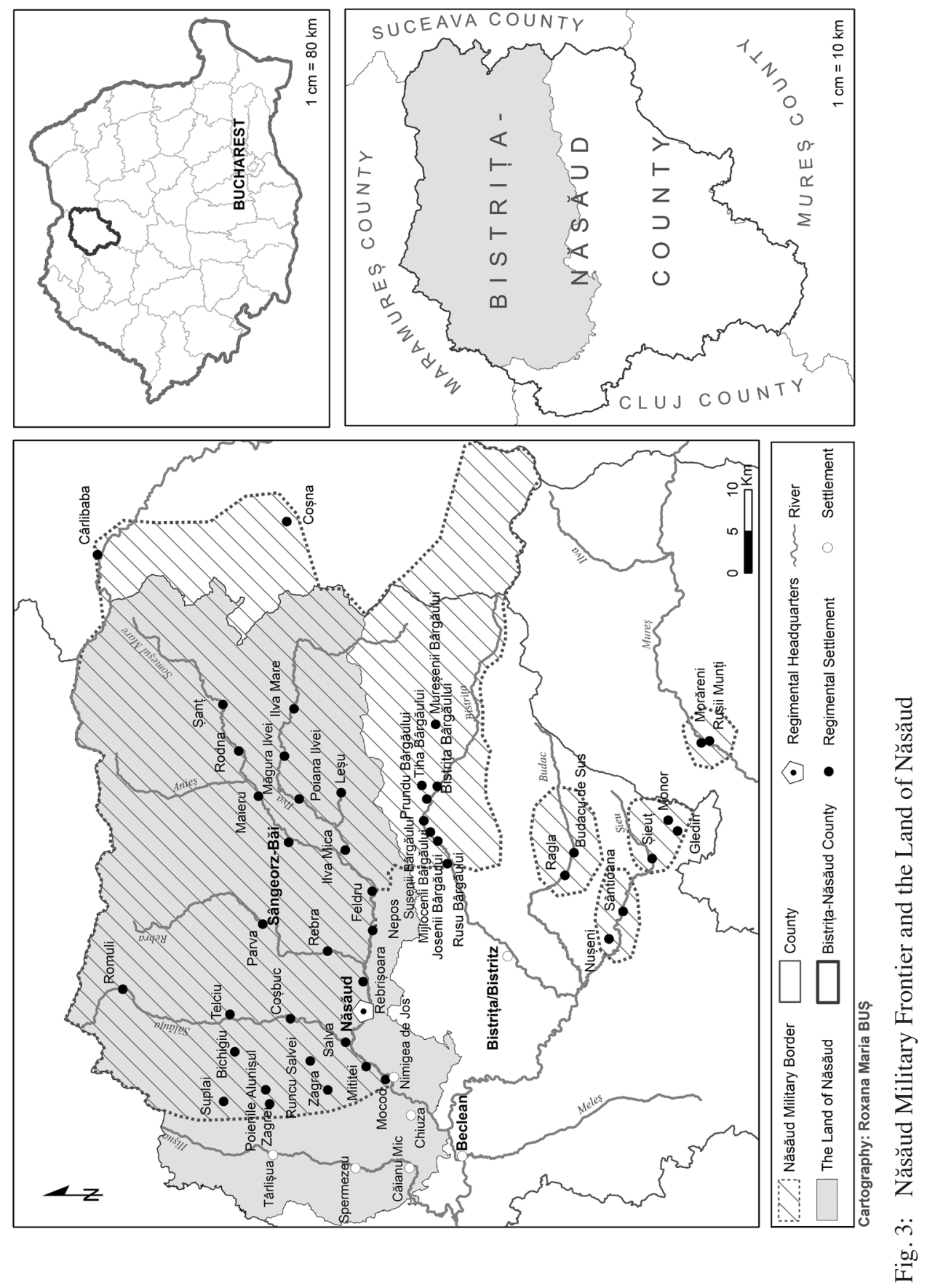
- statua valachorum (Şotropa 1975, p. 436; PöLL 2013, p. 436). Through this statute, they brought forward a document issued by Matthias Corvinus in 1475 through which the Rodna Valley District was transferred from the authority of Szolnok-Doboka County to that of the town of Bistriţa "on condition that the Romanians were recognised as free people and had the same rights and freedoms like the other inhabitants of the town" (LUMPERDEAN 1994, p. 141). Through this reference, it seems that in the inhabitants' mentality in the Someşul Mare Valley there had been already present the idea that they were free peasants and that was why they were open for implementing such a military system that guaranteed them that lost right. The people of the region were more flexible when taking decisions and thus quite open to the system that the Austrians proposed.

Another psychological argument was that of reconciliating the situation of the population in the Someşul Mare Valley about the old conflicts they had with the Saxon population in Bistriţa related to the limits of their settlements and to the grazing land. The lack of any solution to people's complaints for this century-long problem lead to disputes between the Romanians and the Saxons. Territorial conflicts and frictions over the right to use the grazing land (The Năsăud Military Frontier District was neighbouring in the west and south-west the district of the Saxons in Bistriţa.) were the most signficant between the Romanian settlements of Nepos, Feldru, Ilva Mică and the Saxon ones of Livezile (German Jaad), Dumitra (German Mettersdorf), and Pintic (German Pintak or Tekendorf).

The psychological consequences were strong for the inhabitants, first of all because of the free people statute instead of being serfs. Secondly, there was a change in the relationship with the Saxon population in Bistriţa (The Romanians no longer depended on those in Bistriţa.) and thirdly they gained a special place within the Romanian territories (LUMPERDEAN 1994, p. 144), similarly to the other Romanian regiments. In the official document for implementing the Military Frontier system - Suplex Libellus Valachorum the inhabitants of the military districts were considered the military representatives of the Romanian population (ProDAn 1984, p. 480).

The setting up of the Transylvanian Military Frontier was a long process, had some setbacks and there were also several frictions and conflicts between the Austrian administration and the local inhabitants. It is important to stress that the population affected by the militarisation had different starting points, which influenced the position of the various groups towards the militarisation. For the Szekler population, the militarisation meant loosing privileges and being subordinated to strict military structures. The Romanian population had advantages and gained privileges from being members of the Military Frontier. The nobility was not satisfied with the idea of losing serfs and, on several occasions, disregarded the authority. The population expressed its discontent with the delayed implementation or with the militarisation process through revolts and disobedience that was followed by retaliatory measures ordered by Baron Bucow: In 1761, in Transylvania he burnt several churches (PăCURARIU 1992, p. 220).

The event on the $10^{\text {th }}$ of May 1763 near Salva village, on the place La Mocirlă, and Tănase Tudoran's initiative remained as an echo in the people's memory in the Năsăud Military Frontier District. This man, who was 104 years old, instigated the people to revolt and not accept to be part of the regiment because the Empress did not keep her promises 
towards them (to be free people and offer their children the possibility to study). The main complaint was that they were still serfs and their free people's rights were granted only in writing, not in practice.

Only three months after that event did the proper militarisation of the Năsăud area take place, and near Salva village people took the oath for the Second Imperial Infantry Transylvanian Romanian National Regiment and for the Cavalry Regiment. Their main tasks were to defend, both during peace and especially during war periods, the roads and to maintain the security (to track down offenders, illegal commerce, and illegal border trespassing).

The Military Frontier District mentality has become a syntagm that defines the way of thinking in a space and a community as a result of the functioning of the district between 1762 and 1851 . This is characterised by a series of features due to the cult of heroes, the cult of the good emperor, a strong sense of property, and the rights that are related to the free men statute. The cult of the heroes appeared after the inhabitants of the district participated at a series of wars as soldiers of the Austrian Empire: The war against Prussia, and the wars against the Ottomans (1788-1791), the ones against the French (1793-1801, $1805,1809,1812$, and 1813-1814), etc. (Ilovan 2009, p. 85). Recently published archive documents (KLEIN 2006, p. 57) mentioned that: "The inhabitants of the Romanian Military Frontier districts distinguished themselves in all wars through courage, boldness, endurance, cold blood and bravery, beautiful qualities that the great army leaders of the $19^{\text {th }}$ century recognised: Emperor Napoleon I and the Archduke Carol."

The "Military Frontier district society" had at its basis the family as a community value. Underlining this, they set up new regulations in 1766 about the organisation, concession and the inheritance of property in the Military Frontier district families, and in 1808 they issued an order on the property right in the region of Năsăud (VLAșin 2012, pp. 11-12).

The geographical space, the agricultural, and the mental (psychological) one had an important role in the people's mentality in the Military Frontier district. This was true for centuries, even after the military system ceased its existence. The first land system organised in the $19^{\text {th }}$ and $20^{\text {th }}$ centuries is still stable for present real estate issues.

School and then military education offered the population in the area a gateway to knowing Europe due to new mobility possibilities, and to study and learn thoroughly technical and humanist scientific fields in Vienna. In addition to these, many times teachers and priests from the region represented the population in front of the Emperor Joseph II while trying to get solutions to their problems directly from the ruler of the Empire and not so much from the commanders of the regiment (Bolovan \& Bolovan 2009, p. 442).

\subsection{Present identity landmarks}

\subsubsection{Their land, their education, and their faith}

The Austrian Military Fronitier as a whole was a territory with a unique ethnic, religious and cultural compound, with several different population groups. The creation 
and cultivation of a unitary frontier guard identity was essential for the existence and well-functioning of the Frontier. In the process of the Frontier identity establishment, the administration underlined its privileged position compared to the status of the civil population from the neighbouring provinces. The Frontier guards were free tenants, yet subordinated to the military hierarchy and under a permanent commitment to carry out military service, but in a better social status as the non-military population from the adjacent civilian area living as feudal subjects.

The spatial and political-administrative dichotomy of 'frontier - province' was enhanced by the 'soldier-peasant - serf' opposition, which was a defining element of status and identity. These major categories were complemented by the features 'military - civil' and 'free - feudal subject', which defined the Frontier identity (HAVADI-NAGY 2010, 2013).

The social and military disciplining and the construction of their unitary identity as "free peasant soldiers" meant changes in the frontier inhabitants' habits and life style, the introduction of rules and regulations, and the creation of new shared values. This longsome complex process was realised with a series of measures in areas like territorial planning and organisation, as well as with economic, military, social, educational, and confessional initiatives.

The disciplinary and civilisation measures meant to educate the Frontier society in a monarchical spirit, to turn them into loyal subjects of the Empire. Due to the militarisation and civilisation measures, the Frontier society was characterised by discipline, responsibility, obligations and constraints, manifested through a special identity and way of life. In accordance with this experience, the population adopted a way of thinking and reasoning characteristic of military institutions and structures, and the Frontier society followed a different evolution path than the population under civil administration ( $\mathrm{H}_{\mathrm{A}}-$ VADI-NAGY 2010, 2013).

The region of Năsăud defines itself through social, economic, and cultural achievements realised during the Military Frontier District period and that continued after this system ceased to exist. They built a part of their identity on the basis of this glorious period. Comparing with the centuries before the Military District was extended to Northern Transylvania, the Romanian population received certain political rights, experienced a positive social mobility, and economic welfare (Mureșianu 2000). In this context, the long ethnographical tradition of the 'land' as a heritage place for Romanian language and Orthodox religion was further promoted and adapted to the new political conditions. Thus, the identity of the Land of Năsăud is two-folded: Both the 'land' features and the Military Frontier advantages contributed to its construction (ILOVAN 2009). These features are reflected also in the answers of the respondents.

"The consciousness of belonging to the 'Năsăud Frontier' is one of people's fundamental features from which, unfortunately, come only rights! They emphasise the past as a period with high social, economic, and especially cultural attainments." (43 years old archiver from outside the region)

A recurrent answer is the one including three fundamental elements for people's self-portraying (i.e. the property right over the land, the support of the school and of the 
Church as institutions, which marked their existence, becoming, and above all emancipation) and these were put always in direct relation to the Military Frontier District period.

"The cult of the land, of property in general, the attachment towards the Church and school." (50 years old university professor)

Respondents considered that identifying the School and Church as the institutions that really marked their becoming is a defining trait for proving people's belonging to the Romanian nation. As a result, they considered the region as a replica at another scale of the entire country.

“People's aspirations are those related to trusting life, and the thirst for culture kept alive by the schools in Năsăud and supported by the Church make these people consider themselves as dignified descendants of the Romanian people." (65 years old retired teacher)

The inhabitants of the region manifested themselves as having a cult of the land both in daily situations and in literary works. The novel "Ion" ('John') (REBREANu 1986) by one of the most appreciated Romanian writers, Liviu REBREANU - who was an inhabitant of the region - presents the inhabitants from two perspectives: Answering to the call of love and to the call of land, the latter being the one who regulated human and social relations in the traditional rural communities in the Land of Năsăud and in the homonymous Military Frontier District). The collectivisation process did not affect this region due to practical reasons (restrictive geomorphological conditions), but inhabitants' perception is that their well-known cult of land helped them escape collectivisation.

"A feature of the inhabitant of the region, of the peasant who descended from the 'black coats' was his almost organic love for his land. In Suplai village, a woman called Docea dared to defend her property right over a piece of land that her parents promised her in front of the priest when she got married and she sacrificed her freedom for that land: She hit with a spud the person who wanted to mark the limit of the land wrongfully and thus she was jailed for three years. Her feeling of ownership was so strong that nothing else mattered." (48 years old entrepreneur)

or

"The people of this region did not undergo collectivisation. Cluttered between hills, they have a quite developed sense of property, and even during Communist times the law trial between two inhabitants of this region for a really small piece of land was presented as a model (i.e. case study) to the students at the Faculty of Law from the University in Cluj." (38 years old teacher)

Another identity-defining feature for the inhabitants of the region is their obvious feeling of belonging to their community, that some of the respondents considered stronger than in other regions. Such an assertion made one of the respondents who naturalised in 
the region after getting married there, thus being able to look to the community also with the outsider's eye.

"The inhabitants of Năsăud region are deeply attached to their roots. Even though in the statistics they have the inclination to be the first in the top of those who migrated for work to Western Europe, in another chapter, not written yet, of the ones who return home, they are the first in that top, too. They are very faithful to their values and this makes them part of a larger historical and social context. This faithfulness is hard to copy and understand by outsiders. Even those who left the region for good are still related subliminally to the ethnic, geographical, and social paradigm, which pulses in these places ... the impressing capacity to always come back, even more rarely, to the native community." (38 years old priest, journalist and speleologist from outside the region, but living there at present)

\subsubsection{Their polarising centre}

The features of the main polarising centre, the town of Năsăud, were also multiplied during the Military Frontier District period, emancipation through education being one of the most significant ones even nowadays.

“The banner of the Military Frontier spirit.” (50 years old university professor)

or

"Military Frontier town." (26 years old primary grades teacher)

or

"The imprint left by the militarisation of the region, a place of culture and intellectuality and the possession, since 1870, of the cadastre system that led to strengthening the people's property sense in this region." (34 years old teacher)

or

"Military, administrative and cultural capital of the Someş Valley, a breeding place for great cultural values: Over 100 PhD owners, over 50 university professors, 18 members of the Romanian Academy who went to school in Năsăud." (59 years old teacher)

or

"Military Frontier town, old tradition of the pedagogical system with a heritage of traditions and customs." (53 years old engineer from outside the region)

or

"The town of Năsăud is well known due to the fame of its schools." (52 years old court clerk)

In this region, people considered education as the most valuable good that somebody could gain and that parents could ensure for their children.

"On the occasion of the first edition (2003) of 'Fire de tort' - a meeting of the writers and people of culture in Bistriț-Năsăud County, in the house of the old 
Anchidim Ureche, peasant poet from Poiana Ilvei, in a place of honour, in his guest room, under an icon, I saw an old book, open at the front page, where I could read a dedication that a great grandfather wrote for his grandchildren to pay attention to and which I quote: 'You should keep in mind dear grandchild that the love for education is a gift greater than any assests.' I am sure that this is an edifying perspective upon old times peasants' mentality, but which, unfortunately, has faded away lately." (60 years old teacher)

This positive perception of learning and of the School is attested by the Military Frontier people's choice after the regiment ended, that of financially supporting their descendants' education through the funds that had initially a military destination. They transformed the Military Frontier funds into civil ones (the agreement from 1861-1862) that up to 1918 "supported entirely the Romanian interests both through financial help for the schools in the area and through bursaries offered to apprentices, pupils and university students descending from Military Frontier people." (URECHE 2001, p. 13; see also DarABONT \& ONOFREIU 2002, p. 259)

"I underline two determining factors for what Năsăud has become:

1. The power of sacrifice for the community - Tănase Tudoran, martyr for social justice and Orthodoxy. And accepting the Agreement and voting the Foundational Instrument through which the Military Frontier families renounced to their financial rights in favour of creating the School Central Fund and the Bursary Fund. Up to 1948, over 4,000 pupils, university, and PhD students benefited from these. These also funded entirely the Military Frontier High School, the communal schools and all the other schools in the region until 1923.

2. The educational policy and that of teachers in the $19^{\text {th }}$ century (imposed especially by the Vicar Grigore Moisil) on:

- selecting the best pupils from all Military Frontier villages and funding their high school (in Blaj and Năsăud), university (in Vienna, Graz, Rome [Roma], Lvov [L'vìv], Berlin, Prague [Praha], and Budapest), and PhD studies;

- signing contracts with the bursary PhD students to return as specialists to the Năsăud Military Frontier region;

- stimulating the teachers to remain in the schools of the region and this led to the appearance of highly competitive didactic teams (those with PhD: Paul Tanco, Artemius Publiu Alexi, Constantin Moisil senior, Ion Mălai and others between 1865 and 1900), including the 15 academicians from the present 18." (59 years old teacher)

\subsubsection{Their traditional costumes}

Some respondents related the characteristic features of the traditional costumes in the Land of Năsăud to the Military Frontier period. 
"The hat with peacock feathers, a unique element, although not characteristic to the entire Military Frontier area, has become emblematic. The Military Frontier breastplate for women." (38 years old priest, journalist and speleologist from outside the region, but living there at present)

or

"A certain pride that they gained during the Military Frontier (1762-1851), through instruction and education, due to some warm-hearted teachers and good patriots (Romanians). Their knowledge horizon opened very much through the military campaigns they took part at in Italy, Germany, and Austria, from where they copied new lifestyles and behaviour models. They wanted to show those also through their costumes, and they managed to create a style that is characteristic to Năsăud region. An element is the hat with peacock feathers, maybe an imitation of the Tyrol [Tirol] hunters and, why not, of the smug peacock. The Năsăud pride perpetuated through the trust and competition spirit among the settlements of the region, each of them wishing to be the first." (59 years old priest)

\subsubsection{Their regional pride}

Taking into account the pride of belonging to the community, named through a specific syntagm - Năsăud pride [fală năsăudeană] (SABĂU 2015, pp. 36-47) -, the respondents identified two causes. One of them was the Military Frontier period and the other one was a secular competition among the inhabitants or among the component settlements of the region.

Most of the respondents, irrespective of their age and level of education, identified the Military Frontier as a source of assuming their superiority due to a good organisation of the community and life in general.

"The Năsăud pride is a superiority feeling towards the provincials. It comes from the Military Frontier tradition and it is and was invoked especially during critical or breach moments in the community life. At the same time, it is an inherent microcosm where it was sufficient to be descendent of the Military Frontier people, to study at George Cossbuc College, to have the academicians; to have the Treasure [the name of the cemetery in Năsăud town - authors' explanation], which is the place where the material past is kept. All these have induced a positive self-assessment feeling." (43 years old archiver from outside the region)

The main advantage that was offered by the creation of the Military Frontier, which induced their superiority, was that of preserving their free men statute.

“'The Năsăud pride' is due to inhabitants' feeling of free people and masters of their property despite all historical difficulties, supporting very cleverly their interests (especially the national and cultural ones) in front of hostile authorities." (50 years old university professor) 
The second advantage generating pride was the early access to education supported during and after the Military Frontier.

“'The Năsăud pride' can be explained primarily through obtaining and perpetuating the free men statute due to the Military Frontier in comparison with the serf villages neighbouring the District. Secondly, through the possibility used by many peasants' children to access diverse levels of education due to the wise directing of the former Military Frontier funds." (60 years old teacher)

or

“" The Năsăud pride' is the feeling of these people from the former Second Military Frontier Regiment (the 22 communes on the Somessul Mare Valley and on the valleys that flow into the Somess) of having the past of free men, open to culture and that gave 20 academicians." (65 years old retired teacher)

or

"The people of Năsăud region are the descendants of the 'black soldiers' (The soldiers' main piece of clothing during the Military Frontier period was the black coat.) The main aim of the Military Frontier Regiment was to defend the citizens' rights and liberties and the territorial integrity. The Regiment soldiers were characterised by heroism, honesty, and loyalty, being praised for their courage by the great Napoleon, during the fights at Arcole: 'If I had 100 black soldiers, I would have won the battle'." (64 years old retired person)

This pride manifested by comparison to the ones from outside the region that did not benefit from similar advantages (freedom and education). But, within the region, this pride was due to successive trials to place in a hierarchy the families within a settlement and the settlements in the entire region.

“"The Năsăud pride' has at its basis a continuous competition among the locals. They try to demonstrate special qualities as traders and first class householders." (45 years old farmer)

or

“"The Năsăud pride' has at the basis the continuous competition between the big families in the villages of this region, based on the age, number of members, the householder' quality and their assets (the land). These criteria were and still are at the basis of the social hierarchy in the village. Another competition is among the villages of the region: Wealthy villages with industrious people that make well known the 'Land of Năsăud' from the 'Someş Valley'. During the market day in Năsăud, each Thursday, one can identify these features in inhabitants' (coming from all the villages on the Somes Valley) language, gestures, and behaviour." (34 years old teacher)

Depending on their education, we noticed diverse sources of pride for these inhabitants: The material competition that the farmers mentioned and that many respondents considered important in the rural area, while the main criterion of assessment within the 
region and in comparison with the others was the cultural achievements for the inhabitants with university education.

"The inhabitants of the town, most of them farmers, with individual households (although they kept the pace with modernity) are very fond of their assets (animals, pieces of land, and even money). Their favourite posture: Their hand on belt in order to show everyone that they are in control. The intellectual boast with the academicians." (58 years old retired teacher)

The above-mentioned advantages are completed by the inhabitants' ignorance that some of the respondents invoked in order to explain this pride.

"I think this pride has several causes: As a mountain area, the medieval pressures to make them serfs were smaller than in other parts; the freemen statute they preserved (sometimes through compromise) gave them certain pride; Military Frontier people; cultural achievements of the area. This pride may be a provincial's complex, even denoting certain ignorance, because Transylvania has also other 'lands' with remarkable achievements.” (53 years old priest)

The Military Frontier people statute, their loyalty to authorities and the heroic deeds justify inhabitants' pride both within and outside the region. They did not defend only the imperial borders and interests, but they also defended their identity that they had created before the appearance of the Military Frontier. New elements were added on an old identity expressed through language, religion, costumes, traditional occupations and traditions connected to the most significant moments in the people's life and in that of the community.

“I explain 'the Năsăud pride' through their great love for tradition, for their ancestors, pride of being the Military Frontier people's descendants, keepers and defenders of the Romanian language, of the traditional costumes, of traditions and handicrafts left from immemorial times." (34 years old primary grades teacher)

or

"Probably because of the Military Frontier area of the Austrian Empire: They were free people, they received from the Emperor the right to education in Romanian and this made them different from other settlements from Ardeal, which did not have this right." (58 years old teacher)

The fact that they carried guns was another source of their pride.

"Proud, army spirit." (59 years old teacher)

or

"This pride comes from the past that, after having the villages of the Regiment systemised, when the inhabitants of these settlements that entered in a special regime as opposed to all the other Romanian areas of the Empire developed their patriotic and national consciousness. Having as a source the results of militari- 
sation (creating Romanian education institutions, the Military Frontier funds, the education bursary system and its beneficiaries' results), the local consciousness developed to grotesques forms, but these are more theoretical than practical. The inhabitants of this region are no smarter than those from another region: History was friendly to them and they could capitalise their native features better than the others. Time changed and from the glorious epoch when the inhabitants of Năsăud region were the only Transylvanian inhabitants that had the right to bear guns, and even as a duty to the Emperor, the only thing left is the echo of their pride." (38 years old priest, journalist and speleologist from outside the region, but living there at present)

They followed their interests with wisdom and practical spirit.

"Being an inhabitant of the region means having the consciousness of belonging to a geographical, historical, political-administrative unit that is more emancipated than the neighbouring regions and this was possible during history due to their offensive spirit and tenacity through which the people here promoted their interests." (50 years old university professor)

The consciousness of the existence of their community.

They consider themselves a community sharing the same costumes, language, noble feelings and truths." (65 years old retired teacher)

or

"Being an inhabitant of the Land of Năsăud is something to boast about, is a pride and at the same time a privilege and an obligation.” (34 years old primary grades teacher)

or

"Being an inhabitant of the Land of Năsăud is a pride and a privilege because this region is well positioned geographically and it is in a wonderful spiritual and folkloric heritage place." (48 years old entrepreneur)

or

"Being an inhabitant of the region means being, first of all, 'a man of honour'. These people have common sense transmitted through genes and a solid elementary education from their families." (23 years old university student)

To be part of the community means having a certain behaviour and mentality, otherwise you are an outsider.

"A free man in the last 300 years, who received ownership of land as an inhabitant of the Military Frontier District, fond of culture (see the example of setting up the present 'George Cosbuc College'), very conservative, unwilling to sell his properties, and fighting for land." (58 years old retired teacher) 
“Assuming the regional pride.” (53 years old priest)

or

"Being part of the community does not mean only living in Năsăud, one has to integrate into the cultural and social atmosphere of the community, contributing individually to its good functioning." (54 years old teacher)

To be part of the community means being perceived from the outside as part of an original community.

"Being part of the community means to relate consciously or not to a flux of values that flows from the past, though the people of the present, united within a matrix that gives them common values that are almost unnoticeable when you are part of the community and they are a source of astonishment when you are not." (38 years old, priest, journalist and speleologist from outside the region, but living there at present)

\subsubsection{Their mentality}

The inhabitants of the region are conservative and emancipated at the same time, probably depending on their education. They are conservative especially related to defining their regional identity, and also nostalgic.

"They accept nothing that comes from outside the region, from those outside the former Military Frontier District." (43 years old archiver from outside the region)

or

"The mentality of the people in Năsăud region is characterised by a 'Military Frontier spirit': The pride of being free and masters in their households; the inclination to become wealthier and this involving love and care for their land; the family spirit and helping each other especially within the family." (60 years old teacher)

But they are emancipated due to their habit of accepting what is new and they proved this during the history of the region.

"Being an inhabitant of this region means to be part of a quite conservative community, which preserves the ancestors' dignity, but open to a certain extent to what is new, especially through the interest in education manifested by the leaders of the community and by peasants as well." (60 years old teacher)

or

"Although characterised as conservative, many of them proved extremely pervious to the globalisation phenomena." (53 years old priest)

or

"People open to the universal, with a high cultural fondness, initiative, the virtue of patience under unfavourable economic and social circumstances." (47 years old university professor) 
They are faithful people.

"They are proud people, who believe in God and in His power, with a mentality open to everything new and beautiful." (29 years old primary grades teacher)

or

"The 50 years of Communism and the 15 years of transition left their print on people's behaviour and mentality so that it is very hard to characterise them. The obvious benefit is that they returned to their faith and to the Christian values. The crude realities of these years marked their mentality and behaviour: The force of unearned money, climbing the social scale through bribery, fraud and, theft." (59 years old priest)

or

"The mentality of the people in Năsăud region depends frequently on their belonging to a community. During Sundays and religious holidays they still gather in certain villages to dance and they discuss the problems of their community. The Church has also an important role in solving the community problems and people have still remained united around this institution." (48 years old entrepreneur)

They are practical and flexible.

"Possessing a traditional mentality, the inhabitant of the Năsăud region is a living classic. One may notice a certain liberalisation of his mentality. Malleable, he will survive." (23 years old university student)

\subsubsection{Their behaviour}

Respondents appealed to inhabitants' respect for authority in order to explain the way they behaved in this region - with respect - no matter whether the respective authority is laic or not.

"About the wisdom of the inhabitants of this region and about their permissible limits, my grandfather from Leşu village convinced me, when he told me that his own grandfather, who was a military in the Imperial Army told him very often that during his life (of 96 years) he had met all kinds of authorities, good and bad, but when the authorities were good people should obey and appreciate them as God's gift for people's kindness, and when they were bad, people should respect and accept them as well, as God's punishment for people's sins." (50 years old university professor)

or

"As Christians, the inhabitants of the region observe rules, they know that any human community is led by authorities and this made them obey and listen to Apostle Paul: 'Every soul should listen to his leaders, but not because of fear, but due to conviction'." (34 years old primary grades teacher) 
"People's respect for authorities and for the written word." (60 years old teacher)

or

"I think that these people have a respect for authority over Romanians' average." (53 years old priest)

Respondents considered the past and their culture as the factors that modelled the inhabitants' behaviour, because freedom was their supreme value, crucial for their existence and for self-defining.

"Their behaviour comes from their way of thinking, that is why they behave like free people, and this type of behaviour is due to their past and culture." (65 years old retired teacher)

or

"Their mentality generates a type of behaviour originating in the years of Austrian leadership, and the fact that they were free could explain their 'boasting'." (57 years old teacher)

The respondents considered that the people of the region had a developed sense of humour, inclined to irony and self-irony.

"They are joyful people, they like to live their life heartily, really optimistic, and good Christians." (47 years old university professor)

or

"They have a lot of humour: 'It is hard to start something, but to give up it's easy'; or when they have a modest corn harvest they say 'they were not tall, but they were rare'." (59 years old teacher)

or

“'John, how are you? Are you sitting and thinking? Not at all, I'm only sitting.' This answer combines irony with self-irony and underlines the importance of thinking as well as the thinker's modesty." (53 years old priest)

or

"When drunk, the people here are very warlike. I am not sure whether Maria Teresa knew this when she formed the Regiment, or because they were militarised they became warlike." (38 years old priest, journalist and speleologist from outside the region, but living there for a long time)

The values they wanted to protect and preserve are their community, country and the Church.

"Individualists on one hand, they are ready to sacrifice themselves for their community, for their country and for their Church." (53 years old priest)

Other respondents consider that nowadays it is difficult to define what people in the region wish from life. 
"Their aspirations are hard to define now when the young are leaving, those between 40 and 60 years old are very busy, and the old are a few and have no say." (58 years old teacher)

\subsubsection{Their flaws}

The origin of the flaws that the respondents underlined is to be traced to respondents' life experience and relate to the features of the nowadays society.

"The people's main flaw is the lack of solidarity, especially when it comes to urgent problems of the community." (64 years old retired person)

or

"Lack of initiative for organisational and productive activities that could capitalise local resources." (58 years old teacher)

The main cause that leads to a gradual loss of the regional specificity and that people should counter-balance or temper its effects is people's present indifference and passiveness.

"In the last decade, I could identify two typologies: The traditional inhabitant of Năsăud town (at a great loss of speed) - proud of the town's past and achievements, fond of culture, schools, and traditions; wishing for revival and for a new start on many directions; the contemporary inhabitant of Năsăud town (with a disquieting upward trend): indifferent to any past achievements; ironic and negativist, jaded by the chances of revival that the town and the region might have." (59 years old teacher)

or

"Many times they live on their history ('we were important ...')." (53 years old teacher)

While writing about flaws, most of the respondents militated in favour of preserving the characteristic features of the region that the human component created: Good organisation and management, respect for the others and for the authorities, respect for family (taking care of the descendants and paying homage to the ancestors), respect for education, and faith. Moreover, the respondents themselves identified solutions to present problems by turning to good account their cultural heritage.

"I think that, for the past generations, preserving and retaining all that was valuable was a high moral duty, transmitted from father to son, but which, unfortunately, has obviously been diminishing to the present day. It is the duty of the Church, of the School and of other institutions (i.e.cultural house, museum, etc.) to perpetuate and preserve this heritage through exhibitions, symposia, festivals, school festivities and activities, etc." (59 years old priest)

or

"The Land of Năsăud has characteristic traditions and customs that we wish to preserve." (54 years old teacher) 


\subsection{Identity and present regional development}

We researched the way in which Năsăud regional identity could lead to development by community's involvement.

There are two Local Action Groups (LAGs) in the frame of the EU LEADER programme in the region: The first is called "The Land of Năsăud" and the second "Bistrița-Năsăud". The two LAGs do not include all settlements in the Land of Năsăud. There is also a very important association - ASTRA - located in Năsăud town and it makes efforts to keep alive the traditions, customs and the cultural values of the region. Beside these, there is a series of projects created by the "Liviu Rebreanu Cultural House" in Năsăud.

In “The Land of Năsăud” LAG we identified projects in agriculture (cattle, sheep, pig breeding, and vegetable farming), and in rural tourism. Agriculture, as a component of regional identity in the Land of Năsăud, a predominantly rural area, has had an important role in people's existence and in community development. The present interest for agriculture through projects shows that traditional activities are still important. Identity is capitalised in touristic projects such as "Creating touristic routes and promoting local cultural traditions for Feldru and its neighbouring areas". These projects have EU funding through the LEADER programme and were implemented between 2012 and 2015 (THE LAND OF NĂSĂUd LAG 2014).

For the "Bistrița-Năsăud" LAG, we identified a series of projects for each component settlement as well as integrated projects funded by the European Agricultural Fund for Rural Development. Thus, the local councils in the area started to realise integrated projects solving their infrastructure problems, benefitting especially from measure "3.2.2. Renovation and development of villages, improving basic services for the rural economy and population, and valorising the rural heritage" (BISTRIȚA-NĂSĂUD LAG 2014). Sângeorz-Băi town, the second polarising centre of the region, could not receive such funds, and neither did Năsăud (from the other LAG), as they were not rural settlements.

The cultural association ASTRA has an essential role for preserving and transmitting customs and traditions in the Land of Năsăud and by organising diverse cultural events: Book presentations, art exhibitions, homages to the Năsăud Military Frontier people, etc. In 2015 took place a thematic trip "Handicrafts and handicraftsmen in the Land of Năsăud", organised by this association. The aim was to discover and valorise the traditions and customs characteristic of this region by taking into account good practice examples as well as realising an experience exchange among schools and cultural institutions from Romania. In this association most of the members are old.

In 2015, they initiated the arrangement of the Năsăud Military Frontier Museum [Muzeul Grăniceresc Năsăudean] for diverse exhibitions and conferences. The same year, they inaugurated in the "Liviu Rebreanu Cultural House" in Năsăud, the Gallery of the Năsăud academicians (with their 21 drawn portraits). They included this gallery into the National Authority for Tourism, thus enabling measures for its touristic promotion. ${ }^{1)}$

\footnotetext{
1) http://ziarultineretului.ro/galeria-academicienilor-nasaudeni-a-fost-inclusa-in-autoritatea-nationala-pentru-turism/
} 
Another significant project is "The Cultural Café" in the foyer of the Cultural House. It hosts meetings of the Năsăud Retired Persons Club, of all culture people or representatives of cultural institutions in the region, it will have a library and will host concerts.

In addition, there is a network of collaborators for the Cultural House in Năsăud: The Volunteer Centre of Năsăud, which was set up by the Eco-Forestry Association through a non-refundable project within the programme The Foundation for the Development of the Civil Society; The Năsăud Association, which promotes the Romanian cultural values and traditions, organising yearly dance and traditional customs ensembles.

Finally, the major cultural projects taking place each year and getting everyone in the region involved (people and institutions) are the following: The Days of Năsăud Town, the contest festival "For Ispas ${ }^{2}$ in Năsăud" ["De Ispas la Năsăud"], The Parade of the Folk Costumes, etc. ${ }^{3)}$

\subsection{Possible solutions for development}

Studies showed that community-based development is sustainable and therefore the existence and preservation of communities where individuals share traditions and values are crucial for supporting peoples' and places' identity. These lead to networking, to strengthening social capital, to more lively communities and to creating social, economic, cultural and environmental opportunities for development. This connection between individuals can be better capitalised in the form of local and regional initiatives, with support from the public administration. At the same time, community-based development strengthens identity.

We propose a series of measures for using territorial identity and social capital. Firstly, as the main association directly related to promoting the identity of the Năsăud region is ASTRA, but it includes mainly the old generation in its voluntary activities, a solution for the sustainable development of its activities would be including the youth.

Secondly, as neither of the two LAGs includes the settlements in the western part of the region, a solution would be that those form a partnership either among them or associate with the settlements in the two existing LAGs. Thus, both their identity and development would benefit.

Thirdly, for sustainability, we propose that the existing associations and groups form networks, thus strengthening people's feeling of belonging to a coherent region and make inhabitants more co-operative, pro-active, and united. Fourthly, co-operation with associations, organisations, groups, institutions, etc. outside the region enable the promotion of Năsăud regional identity and it could become a good practice example.

Finally, the local authorities within the region and people themselves should realise campaigns for promoting their regional identity. They could realise this in schools, churches, during diverse events or informal meetings, as well as during electoral cam-

\footnotetext{
2) The popular name of an Orthodox feast celebrating the Christ's Resurection and marking 40 days after the Easter.

3) http://www.rasunetul.ro/proiecte-ambitioase-ale-casei-de-cultura-liviu-rebreanu-din-nasaud-la-inceput-de
} 
paigns because the elected ones have a significant role in taking decisions and implementing measures for territorial planning and development.

\section{Conclusions}

Results showed that the identity of the region is strong, but the role of social capital for development is rather small and therefore we proposed solutions for capitalising territorial identity. We considered the youth's involvement crucial for transmitting cultural values to future generations.

In the Land of Năsăud, we identified two LAGs with a series of promising projects for the region. Then, we underlined the role of the ASTRA Association through the cultural events and diverse activities that revive the Military Frontier spirit and the older traditions in the region, thus ensuring the link between past and present in what shared values, regional belonging, and pride are concerned.

We concluded that regional identity is a resource that could lead to economic and social regeneration, it could support development initiatives in the Land of Năsăud and implicitly in other 'land' type regions, in former Military Frontier districts, and in other conservative regional communities.

\section{References}

BistriȚA-NăSĂUd LAG (2014), Grupul de acțiune locală Bistrița-Năsăud. Strategia de dezvoltare locală [Bistrița-Năsăud Local Action Group. Local development strategy] - http://www.galleaderbistritanasaud.ro/images/Upload/Strategiirealocari/2014_08_SDL.pdf (Accessed on 14 March 2016).

Bolovan I., Bolovan S.P. (2009), Graniţa militară austriacă şi românii din Transilvania în sec. XVIII-XIX (studiu de caz: zona Năsăud) [The Austrian Military Frontier and the Transylvanian Romanians in the $18^{\text {th }}$ and $19^{\text {th }}$ centuries (a case study: Năsăud area]. In: PoP I.A., ANDEA S. (eds.), Pe urmele trecutului: profesorului Nicolae Edroiu la 70 de ani, pp. 437-446. Cluj-Napoca, Academia Română, Centrul de Studii Transilvane. - http://dspace.bcucluj.ro/ bitstream/123456789/47845/4/Bolovan\%20Ioan-Granita\%20militara\%20austriaca-2009. $p d f$ (Accessed on 2 February 2016).

ButA M.G., ONofreiu A. (2012), Etica utilizării violenţei [The ethics of using violence]. In: Tabor, VIII, 5, pp. 47-52.

Claval P. (s.a.), Regional Geography: past and present (a review of ideas/concepts, approaches and goals). - http://sgo.pccu.edu.tw/geog/chi/b/b1/chapters-culture-geog/b.pdf (Accessed on 2 October 2013).

Cocean P., Ilovan O.-R. (2009), Genesis of a "Slope Land”: The Land of Năsăud. In: Studia Universitatis Babeş-Bolyai, Geographia, LIV, 1, pp. 93-102.

Darabont E., ONOFReIU A. (2002), Sorgintea fondurilor grănicereşti năsăudene. Mărturii documentare [The source of the Năsăud Military Frontier District funds. Archive testimonials]. In: Arhiva Someşană, the $3^{\text {rd }}$ series, I, pp. 225-270. 
Flora Butler C., Flora L.J. (2013), Rural Communities: Legacy and Change, $4^{\text {th }}$ edition. Boulder (Colorado), USA, Westview Press.

HAVAdI-NAGY K.X. (2010), Kriegserfahrungen, räumliche Mobilität und Lebensformen in der Slawonischen und in der Banater Militärgrenze [War experience, spatial mobility and life styles in the Salvonian and Banatian Military Frontier]. Cluj-Napoca, Romanian Academy, Center for Transylvanian Studies.

Havadi-NaGy K.X. (2013), The Banatian Military Border: Aspects of the Influence Exerted by Military Status on Space and Society: In: Faur A., Teicu D. (eds.), Central European Historical Realities. They Jewish Contribution to Urban Development. Banat as a Border Region (14 $14^{\text {th }}-18^{\text {th }}$ Centuries). In: Transylvanian Review, XXII, Supplement 4, pp. 167-179.

ILOvan O.-R. (2008), Raportarea la trecut sau semnificaţia unei perioade istorice pentru identitatea teritorială năsăudeană [Looking back to the past or the significance of a past period for the territorial identity in the Land of Năsăud]. In: Bolovan I., Mureşan C., HărăGuş M. (eds.), Perspective demografice, istorice şi sociologice. Studii de populaţie, pp. 363-406. Cluj-Napoca, Presa Universitară Clujeană.

ILovan O.-R. (2009), Ţara Năsăudului. Studiu de Geografie Regională [The Land of Năsăud. Study of regional geography]. Cluj-Napoca, Presa Universitară Clujeană.

ILovan O.-R. (2013a), Capitolul I: Cadrul natural şi administrativ-teritorial [Chapter I: The natural and territorial-administrative context]. In: Lechintan V., Onofreiu A., Prahase M. (eds.), Fabricat în Runcu Salvei. Aspecte monografice, pp. 15-82. Cluj-Napoca, Editura Eikon.

ILovan O.-R. (2013b), Regenerarea Țării Năsăudului [Revival of the Land of Năsăud]. In: CocEAN P., Filimon L. (eds.), "Thările” din România ca teritorii de proiect, pp. 65-76. Cluj-Napoca, Presa Universitară Clujeană.

JoRdAn P. (2015), Die österreichische Militärgrenze gegen das Osmanische Reich. Ein geographischer Blick auf ihre Nachwirkungen bis heute [The Austrian Military Frontier against the Ottoman Empire. A Geographical Glance on Its Impact until the Present Day]. In: Österreich. Geschichte, Literatur, Geographie, 3, pp. 245-266.

Keating M. (2008), Noul regionalism în Europa Occidentală. Restructurare teritorială şi schimbare politică [The new regionalism in Western Europe. Territorial restructuring and political change]. Iaşi, Institutul European.

KLEIN K. (2006), Istoria de arme a Regimentului cezaro-crăiesc de infanterie nr. 17 naţional român transilvănean [The army history of the $17^{\text {th }}$ Imperial Transylvanian National Romanian Infantry Regiment]. In: ONOFREIU A., Bolovan I. (eds.), Contribuţii documentare privind istoria regimentului grăniceresc năsăudean. Bucureşti, Editura Enciclopedică.

Lee J., Arnason A., Nightingale A., Shucksmith M. (2005), Networking: Social Capital and Identities in European Rural Development. In: Sociologia Ruralis, 45, 4, pp. 269-283.

LUMPERDEAN I. (1994), La longue dureé în mentalitatea şi limbajul grănicerilor năsăudeni. Repere economico-sociale şi politico-naţionale [La longue dureé in the inhabitants' mentality and language in the Năsăud Military Frontier District]. In: Revista Bistriţei, VIII, pp. 137-145.

Mureșianu M. (2000), Districtul grăniceresc năsăudean (1762-1851). Studiu de geografie istorică [Năsăud Military Frontier District (1762-1851). Historical-geographical study]. ClujNapoca, Presa Universitară Clujeană.

Oliveira J., Roca Z., Leitao N. (2010), Territorial Identity and Development: From Topophilia to Terraphilia. In: Land Use Policy, 27, pp. 801-814.

PAASI A. (1986), The institutionalization of regions: a theoretical framework for the understanding of the emergence of regions and the constitutions of regional identity. In: Fennia, 164, pp. $105-146$.

PAAsi A. (2003), Region and place: regional identity in question. In: Progress in Human Geography, 27, pp. 475-485. 
PAASI A. (2009), The resurgence of the "region" and "regional identity": theoretical perspectives and empirical observations on regional dynamics in Europe. In: Review of International Studies, 35, pp. 121-146.

PAASI A. (2011), The region, identity, and power. In: Procedia Social and Behavioral Sciences, 14, pp. 9-16.

PĂCURARIU M. (1992), Istoria bisericii româneşti din Transilvania, Banat, Crişana şi Maramureş pâna în anul 1918 [The history of the Romanian Church in Transylvania, Banat, Crişana, and Maramureş until 1918]. Cuj-Napoca, Editura AAVFC.

Pöll C. (2013), Die österreichische Militärgrenze [The Austrian Military Frontier]. In: historia. scribere, 5, pp. 427-444. - https://webapp.uibk.ac.at/ojs/index.php/historiascribere/article/ viewFile/276/154 (Accessed on 10 May 2016).

Prodan D. (1984), Supplex Libellus Valachorum: Din istoria formării naţiunii române [Supplex Libellus Valachorum: From the History of Romanian Nation-Building]. Bucureşti, Editura Ştiinţifică şi Enciclopedică.

RĂSUNENTUL (ed.) - http://www.rasunetul.ro/proiecte-ambitioase-ale-casei-de-cultura-liviu-rebreanu-din-nasaud-la-inceput-de (Accessed on 3 April 2016).

Rebreanu L. (1986), Ion [John]. Bucureşti, Editura Cartea Românească.

Roca Z., de Nazaré Oliveira-Roca M. (2007), Affirmation of territorial identity: a development policy issue. In: Land Use Policy, 24, pp. 434-442.

SABĂU C.S. (2015), "Şi ne-au făcut din grăniţeri, ţărani..." Mentalităţi colective în satele năsăudene foste grănicereşti în a doua jumătate a secolului al XIX-lea ["And they made us peasants from Military Frontier people ..." Collective mentalities in the villages of the former Năsăud Military Frontier District in the second half of the $19^{\text {th }}$ century]. Cluj-Napoca, Editura Mega.

Scotт J. W. (2009), Systemic Transformation and the Implementation of New Regionalist Paradigms: Experiences of Central Europe and Latin America. In: Sсотт J.W. (ed.), Decoding New Regionalism. Shifting Socio-political Contexts in Central Europe and Latin America, pp. 19-49. Farnham, Ashgate.

SCRIDOn I., Ilovan O.-R. (2015), The Zipsers' ethnic identity in Vişeu de Sus/Oberwischau, Romania, in the context of inter-ethnic relationships. In: Mitteilungen der Österreichischen Geographischen Gesellschaft, 157, pp. 151-168.

Şotropa V. (1975), Districtul grăniceresc năsăudean [The Năsăud Military Frontier District]. ClujNapoca, Edura Dacia.

Šugar H. (2010), The Frontiersmen in the Austrian Military Border in Sixteenth and Seventeenth Centuries. In: Suppan A., GrÄF M. (eds.), From the Austrian Empire to Communist East Central Europe, pp. 49-64. Würzburg - Münster, LIT.

THE LAND OF NĂSĂUD LAG (2014), Plan de dezvoltare locală GAL Țara Năsăudului. Varianta modificată [The Land of Năsăud LAG - Local development plan. Modified version] - http://www. taranasaudului.ro/pdf/SDL\%20MODIFICATA\%20VARIANTA\%204\%20NOIEMBRIE\%20 Tara\%20Nasaudului\%202014.pdf (Accessed on 14 March 2016).

Tuan Y.-F. (1990), Topophilia - a study of environmental perception attitudes and values. New York, Columbia University Press, Morningside Edition.

URECHE L. (2001), Fondurile grănicereşti năsăudene (1851-1918) [The Năsăud Military Frontier District Funds (1851-1918)]. Cluj-Napoca, Presa Universitară Clujeană.

VANIČEK F. (1875), Spezialgeschichte der Militärgrenze aus Originalquellen und Quellenwerken geschöpft [The Military Frontier's special history, based on primary sources and source works], Vol. III, Wien, K. und K. Hof- und Staatsdruckerei.

VLAșin C. (2011), Crearea fondurilor grănicereşti năsăudene [Creation of the Năsăud Military Frontier District funds], pp. 86-103. - http://www.arhivelenationale.ro/images/custom/image/ serban/2014/RA\%201\%202011/09\%20vlasin,\%20cornelia.pdf(Accessed on 10 May 2016). 
VLAșIN C. (2012), Proprietatea grănicerească în timpul regimentului II românesc de graniţă [The property of Frontier guards in times of the Second Romanian Frontier Regiment]. In: Arhiva Someşană, $3^{\text {rd }}$ series, XI, pp. 11-16.

ZiARUl Tineretului (ed.) - http://ziarultineretului.ro/galeria-academicienilor-nasaudeni-a-fost-inclusa-in-autoritatea-nationala-pentru-turism/ (Accessed on 7 March 2016). 